\title{
The Influence Of Endogenous Mother's Bargaining Power On Her Child's Schooling: Evidence From Pakistan
}

\author{
Ambreen Fatima \\ Faizan Iftikhar \\ \& \\ Humera Sultana \\ Applied Economics Research Centre \\ University of Karachi
}

\begin{abstract}
This paper is an attempt to identify intra- household relationship among its members and its effects on child schooling. Specifically the article is designed to look for the answers of following questions: what are the principal determinants of power of mothers in making decisions or what is an appropriate way to measure decision- making power? How does this decision- making power of mothers in the household affects child schooling decision? Is this effect non-linear and non-monotonic as predicted by all recent literature? The objectives are explored by using the Living Standard Measurement Survey data of Pakistan for the period 2007-08. Article shows that the effect of any additional power given to mother's increases child schooling but the effect is not non-monotonic.
\end{abstract}

Keywords: Child Schooling, Collective Household Decision Making Model, Mother's Decision Making Index.

$$
\begin{aligned}
& \text { تلخيص }
\end{aligned}
$$

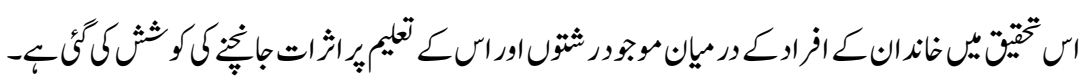

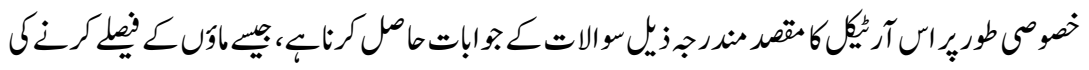

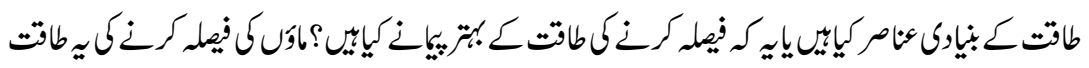

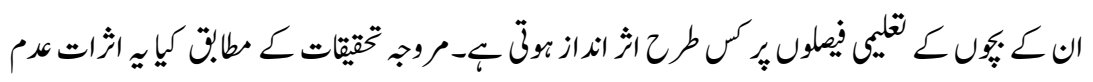

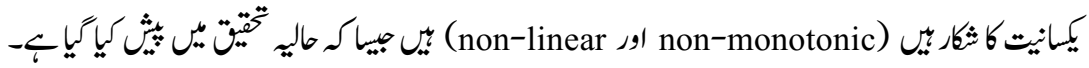

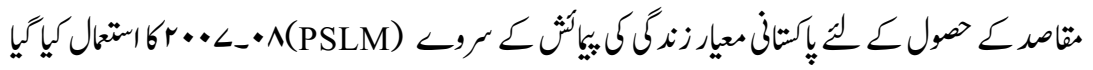

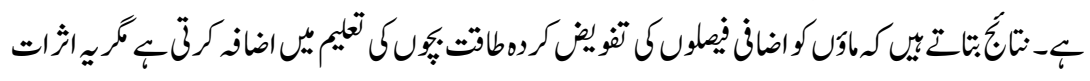

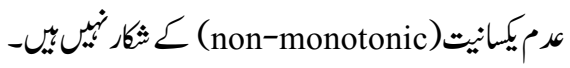

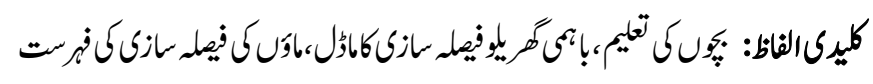




\section{Introduction}

The traditional approach of modelling household on the basis that its members' preference can be categorized by single utility function, has been challenged in recent years. Now the utility function of the household models incorporates divergence and even conflicting preferences among the family members. This paper is an attempt to identify this intra- household relationship among its members and its effects on child schooling. This study is specifically designed to look at the effects of a mother's decision making power on her child's schooling. This collective model of the household is explored by using the Living Standard Measurement Survey data of Pakistan (PSLM hereafter).

The foundation of the paper is based on the collective household model approach using data of Pakistan. Although Amin (1995) and Hakim and Aziz (1998) have rejected the collective model approach for Pakistan. Because of the prevailing traditional and cultural norms that restrict women's position in the household and the male head considered as the household decision- maker, they argue that it is reasonable to assume that the unitary model dominates in Pakistan. But as in recent years Pakistan has experienced some changes in women's roles both within and outside household. Realizing the fact, Hou (2011) using the PSLM data of 2005 has rejected the existence of unitary model for Pakistan. Hou (2011) has examined the effect of women decision making power on the budget share, caloric intake and children's school enrollment. He found out that when women have more decision making power at home, household tends to spend more on women's preferred goods such as clothing, education, non-grain items and children's education particularly girls who are more likely to be enrolled in the school.

Internationally evidence suggests that when women have more decision- making power they spend more on food. For example; Hoddinott and Haddad (1995) found that women's income is positively related to food items while negatively related to alcohol and cigarettes. However, Lancaster et.al., (2006) working on an Indian data set found out that the budget share and women's decision making power is U-shape. Basu (2006), using a theoretical framework of intra-household model, predicts that if a woman has more decision- making power she will have access to a greater share of the income produced by children and thus may benefit from child labour. School enrollment might therefore decline as a result of increased child labour. Maitra and Ranjan (2006) found that, in South Africa, there is no clear evidence that the identity of income earners affects household expenditures; and Felkey (2005) suggests that, in Bulgaria, the relationship between women's bargaining power and household well-being is nonlinear and non-monotonic. 
The objective of the paper therefore, is to explore the effects of a mother's decision- making power on her child's schooling decision. In addition the paper also explores the non-linear and non-monotonic relation for Pakistan as suggested by Felkey and Lancaster for Bulgaria and India. More specifically this study aims to look for the answers of following questions:

1. what are the principal determinants of power of mothers in making decisions or what is an appropriate way to measure decision- making power?

2. How does this decision- making power of mothers in the household affects child schooling?

3. Is this effect non-linear and non-monotonic as predicted by all recent literature?

If the answer turns out to have significant effects then it would have considerable policy implications. Therefore, the paper tries to explore the answers of all these questions.

The rest of the paper is sub-divided into following sections: section 2 provides detail on the data set employed, methodology used to measure the decisionmaking power and outlines the econometric specification, section 3 discusses the main findings while section 4 presents a conclusion.

\section{Data and Methodology}

The choice of proper approach for measuring decision making power depends on availability of the data. Here, the data of Pakistan Social and Living Standards Measurement Survey (PSLM) 2007-08 is used to analyse the effect of mother's decision- making power on her child's schooling decision. PSLM is a national level household survey having information on a range of social issues. A separate module in PSLM on women decision making status provides a good opportunity to investigate the effects of a mother's decision making power. As the article is interested in knowing the effects of a mother's decision- making power on her child's schooling the article restricts the sample to all those women who have children. Hence this study is based on a subset of the PSLM data. The women's decision making module ${ }^{1}$ has questions related to employment, purchases of household food and clothing, taking medical treatment and recreation decision. Women were specifically asked about:

\footnotetext{
${ }^{1}$ Although PSLM also includes questions regarding the women own education decision, use of birth control and decision about having more children. But as education decision is mostly taken by the parents of the mothers at a very early age, where one cannot influence the decision hence it is highly unlikely that this will affect the decision making power of her today while, the decision about birth control and having more children concern religious, social and cultural norms. Hence these factors are not considered relevant here.
} 
i) Who takes the decision whether you can seek or remain in employment?

ii) Who takes the decision about purchase of the following items:
a. Food
b. Clothing
c. Medical Treatment
d. Recreation and Travel

The answers to these questions were categorized as:

i) Women alone decide

ii) Both Women and Husband decide

iii) Husband or other members of the household Decide

A mother is considered to have decision making power on a particular issue if she jointly or by herself takes the decision. Specifically 3 points are assigned to all the decisions that are taken by the mother herself while 2 points are assigned to all the activities in which joint decision takes place. This is because a mother is considered to have some degree of power if she jointly decides with her husband about certain decisions for example in issues such as getting into an employment and decision regarding recreation and travel. Such decisions cannot be taken by mother alone. 1 point is assigned to all the decisions taken solely by the husbands or the elders of the house. A composite score is thus constructed on the bases of all the decisions. A scale hence consists of score ranges from 1 to 3 in each decision category.

After applying an appropriate scale to all categories, principal component analysis (PCA) is used to determine the weights that each decision category should carry. Applying PCA after making a scale from 1 to 3 for all the decisions is due to the fact that PCA is not applicable to the variables that are categorical. The literature often points out that creating dummy variables from categorical variables can solve the problem. But here to avoid creating a number of dummies, a scale ranges from 1 to 3 were assigned to all indicators. In this way the article comes up with a set of indicators that represent that, the higher the value the higher will be the decision making power. Each indicator differs in terms of the small and large decisions i.e. purchasing food is mainly done by women in Pakistan and in this category a woman has the highest decision- making power over rest of the members while travelling and going for recreation decisions are mostly done jointly by household or elders of the household, hence in such decisions women would have low decision- making power. Keeping the fact that all these indicators of decisions vary in terms of small and big decisions, PCA is applied to assign the weights across different indicators of decision making. 
PCA is a famous statistical technique commonly used for data reduction process. Each component is a linear weighted combination of initial variables that captures the common patterns. The strategy followed is very simple: there are 5 decisions and 3 categories about who takes the decision (mothers alone, jointly by both parents and by husband or other family members), that are all together used to determine mother's decision making power.

The first principal component is used to measure mother's decision making power. The first principal component explains about $64 \%$ of the variability in data. Hence consider as suitable to represent decision- making power of women. As each decision category takes a value of 1,2 or 3, depending on who is taking the decision hence, if a category moves from 1 to 2 (or 2 to 3 ) the index increases by the amount of its weight.

\section{Issue of Endogeneity in Decision Making Index}

Recent economic literature working on relative income share of females and the ratio of years of female to male schooling has predicted the presence of endogeneity in the two. For example Emerson and Souza (2007) argue that male and female may have different preferences for the outcomes for their children. Their preference depends on many factors such as gender of the child. Hence allocation of resources within a household may be seen as the result of some kind of resolution of the preference differences. This resolution further depends on their relative bargaining power. This power again depends on many factors and hence considered as endogenous. For example, women who bring more income to households are most likely to have greater decision- making power. Roushdy and Namoro (2007) also argue that the extent to which male and female preferences affect the decision making process that in turn determines child welfare is itself endogenously determined. According to them male and female relative decisionmaking power depends on their individual and some common household or social characteristics that may again be determined within the model. Moreover, according to Basu (2006) the literature modelling the impact of intra-household balance of power on decision- making also tends to ignore the opposite relation i.e., the effect of household decisions on balance of power.

In short, in order to generalize the effect of a mother's decision making power on child schooling, first presence of endogeneity is checked. After checking the endogeneity, mother's decision- making power is estimated and then the predicted values from the mother's decision making model are used to estimate the child schooling function. More specifically after checking the endogeneity problem in the mother's decision making power for the two decisions, first mother's decision- making power is estimated as the linear function of the distribution factors (that affect the decision through bargaining power) and the factors that 
affect the decision directly (such as household size, gender of the head, living conditions and durable asset index). In the second stage the estimated values of decision making power are used to predict child schooling.

The distribution factors are the variables that affect distribution of power within the household but have no direct effect on individual preferences. Following Reggio (2010) two variables are considered as affecting the distribution of power in the household (i) difference between husband and wife's ages; if the wife is younger than the husband she will have less power (ii) Difference between education attainment level between women and men; the higher the difference the lower will be the women's decision- making power. The model also includes the square terms of each distribution factor as well. Reggio (2010) has also used sex ratio (proportion female vs male) as distribution factor. Following Reggio the article has also included it as a factor influencing the distribution of power but as it does not pass the over- identification restriction it was dropped from the model.

The mother's decision- making power is computed under the framework of instrumental variable regression. The factors that influence decision- making power of mothers directly include household size, gender of household head, and ownership of agriculture land, household living standard, durable asset index and provincial dummies. The provincial variations are included because in Pakistan, in some areas due to development, women are now more empowered than the women who are living in remote areas such as rural areas of Balochistan (most deprived province of Pakistan).

$$
M D M=\alpha+\beta_{1} Z+\beta_{2} X+\mu
$$

Where; $M D M$ represents mother's decision making power, $Z$ represents distributional factors while $X$ are the factors that affect decision- making directly.

\section{Mother's Decision Making Power as a Determinant of Child Schooling}

In the second stage the decision with regards to child's schooling is estimated. The estimated values of mother's decision- making power from the first stage regression are regressed on the child's schooling decision after checking the endogeneity.

$$
\begin{aligned}
& C L_{-} S T=\beta_{0}+\beta_{1} M D M+\beta_{2} P E D U+\beta_{3} C H L D+\beta_{4} H E A D+\beta_{5} H H D \\
& \quad+\beta_{6} P R O V+\pi \quad(2)
\end{aligned}
$$

Where, $M D M$ represents mother's decision making index, $P E D U$ represents sum of parents years of schooling, CHLD represents child characteristics, HEAD represents household head gender, $H H D$ represents household characteristics and 
$P R O V$ are provincial dummies. CL_ST here refers children in school equal 1 otherwise 0. Effect of the mother's decision- making power is estimated using the probit model. Probit model is applied as the dependent variable is binary in nature.

Among the independent variable, first child's own characteristics i.e. his/her age, gender and birth order is explored. The birth order here is measured in ascending order i.e. the first born is with the value of one. The main hypothesis is that the incidence of child labour is more common among the first born than the subsequent siblings. This is because of the fact that in the presence of income constraints, parents are unable to invest in older children but can invest in younger children with the aid of income earned by first born. Therefore, the higher the birth order, the higher will be the probability of child schooling. The literature basically suggests two types of effects. First as more children are born, to a household where resources are constrained, fewer resources will be available per child. Hence younger siblings will receive less education than the older siblings. Alternatively, older children may enter the labour market and contribute towards household income, and as household income stabilizes the young siblings would get a chance to go to schools as explained earlier. As the effect could be nonlinear a squared term is also included in the model. For the age again the study assumes that the higher the age, the higher will be child schooling. But the relationship again could be non-linear. Therefore, the non-linearity is also explored as well.

Secondly, household characteristics include household size, household composition (proportion of male and female in different age groups), gender of the household head, household ownership of agriculture land and indices of living standard and durable assets. For household size this study acknowledges the presence of endogeneity in it. Therefore, before including it in the model the endogeneity was checked by using the probit model for endogenous variables. The instrument used is the gender of first two born. The Wald test of exogeneity (at the end of the table 4) predicts the presence of endogeneity in rural sample only. Hence in the rural sample the endogeneity is controlled by applying the two stage instrumental variable approach while in the rest of the samples this variable enters as exogenous. The effect hypothesised is positive due to the fact that household prefers more children in order to earn more from children thus household usually have large size. Alternatively the larger the size the lower will be the probability for a child to work and higher will be the probability of child schooling. In the presence of older sibling (age greater than 14) the younger sibling are more likely to be at school. Therefore, the effect of the household size on the children age 10 to 14 could be negative. 
In order to capture the effect further, household composition is also included in the model. The household composition variable consists of nine variables showing the proportion of male and females in different age groups. The control group is the proportion of male age 15-65. Moreover, as the household composition variables along with household size and birth order may also be endogenous because of the fertility theory (i.e. household have large sizes or prefer to have higher number of children to earn more form each child) study estimated equation 2 variously by keeping and dropping these variables. Hence, two regressions are estimated, one without household size, birth order and household composition variable while the other by including all these variables. The two models hereafter represent one without controlling for fertility and demographic variables, the other with fertility and demographic variables. Finally parents' characteristics; the model includes sum of father and mother's years of education and the decision- making power of mothers (the variable of interest). Parents' education is measured in terms of sum of number of completed years of schooling and it is hypothesised to have positive relationship with child schooling decision. For mother's decision making power the study again expects that its relationship with the child schooling would be positive. But keeping in mind all recent studies this study also expects that the relation could be non-linear and non-monotonic. Therefore a separate analysis is conducted by including square and quadratic terms to check whether the effect of additional power of mother's in the household is convex and non-monotonic. Child schooling is considered here as a good that generates positive externalities to both parents under the assumption that both parents are concerned about their child. Hence sending children to school generates positive externality. But this effect is for the linear term. As far as the quadratic term is concerned, following Felkey (2005) and Basu (2006), study expects that a further improvement in the mother's relative decision-making power will may impact child schooling differently.

\section{Results}

This section will begin by discussing the determinants of the decision making index and then its effects on child schooling will be explored.

\section{Determinants of Mother's Decision Making Power}

Measuring mother's decision making power is a difficult task, not just in terms of finding suitable indicators to measure this power but also in terms of finding suitable instruments for these indicators. As explained earlier following Reggio (2010), we use two instrumental variables (IV); the difference between husband and wife's age and education. Reggio (2010) also points out that the effect of these factors could be nonlinear; we also include the squared terms of the two IVs as well. F-test and the over identification test are first performed to confirm that 
the IV's used are valid instruments. The f-test shows that the instruments used are not weak. All the instruments representing mother's decision making power also passed over identification test as well. Using probit models for the endogenous variables we then check the presence of endogeneity. The Wald test for exogeneity $[$ chi $2=2.99$ and $\mathrm{p}$-value $=0.22$ with fertility and demographic controls; chi $2=1.19$ and $\mathrm{p}$-value $=0.275$ without fertility and demographic controls] does not reject exogeneity in the all Pakistan sample. However, in rural areas and for boy's schooling the Wald test rejects exogeneity. Therefore the mother's decision making index is entered in these samples after controlling for endogeneity.

Table 1 presents the first stage regression results for mother's decision- making power as dependent variable. Table 1 illustrates that both age difference and the education difference between husband and wife have significant effects on mother's decision making power. The square term of age is also significant while the square term of education difference is insignificant. In the urban sample, only education difference and the squared term of education difference is significant while in the rural areas all four instruments are significant. Looking at the estimated determinants of mother decision making index we find that, the gap between the education of the father and mother significantly reduces the mother's decision- making power. By contrast the sum of parental education increases the mother's decision- making index thus suggesting that education brings change in the society by affecting the cultural and social norms influencing mother's autonomy. Hence more educated partners may provide their wife greater autonomy. As far as age difference is concerned, generally wives are younger than husbands in Pakistan. It was expected that the wives would have less power when their husbands are older than them but the quadratic plot in figure 1 shows a nonmonotonic relationship that is often contrary to this expectation. For age gaps upto 7.7 years, increasing the father's age above the mother's increases the mother's decision- making power. It is only where a father's age exceeds the mother's be nearly a decade or more, that further increasing the gap appears to reduce the mother's decision making power.

Aside from the IVs, some of other factors included in the model also significantly influence mother's decision-making power. For example the proportion of children aged between 6-14, living standard and durable asset indices found to enhance the decision- making power of women while ownership of land, child's birth order and being in a male- headed house, all significantly reduces mother's decision- making power. The effects are more or less same for both rural and in urban areas. As far as provincial variation is concerned, Punjab and Sindh province significantly enhance the mother's decision-making power while Balochistan significantly reduces it; this may reflect the influence of varying cultural norms. 
Figure 1: MDM index and Age Difference

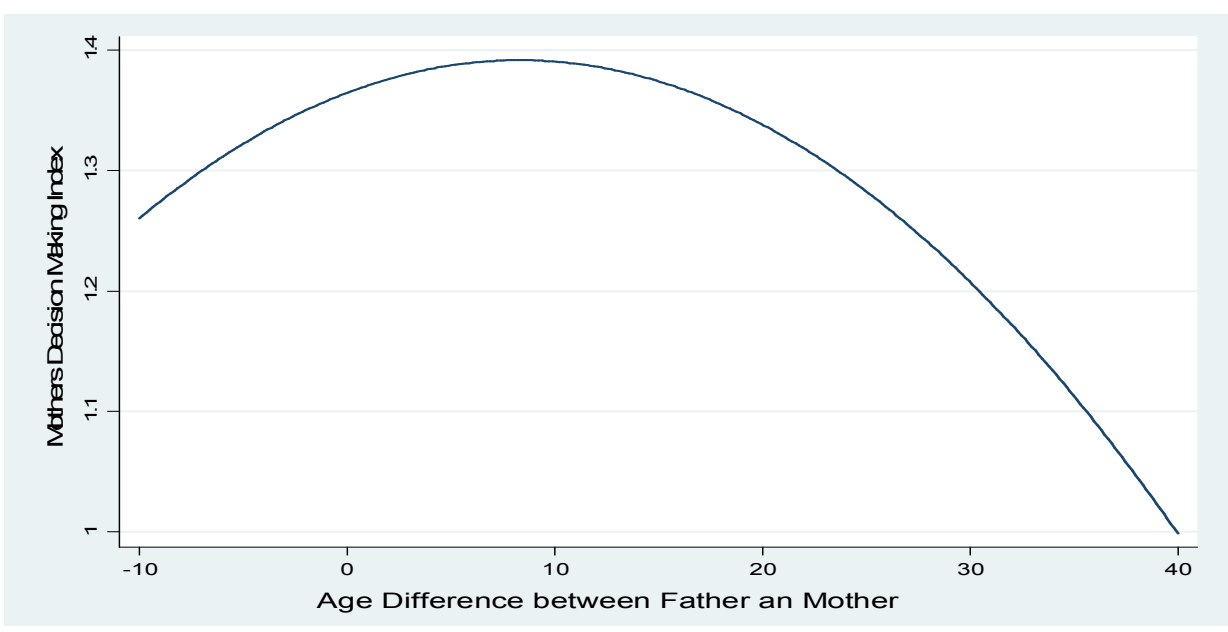

Table: 1

Determinant of Mother's Decision Making Power (OLS)

\begin{tabular}{|l|l|l|l|}
\hline Dependent Variables & All Pakistan & Urban & Rural \\
\hline Age Difference & $0.01(0.1)^{* *}$ & $-0.003(0.62)$ & $0.01(0.02)^{* *}$ \\
\hline Education Difference & $-0.01(0.00)^{*}$ & $-0.01(0.02)^{* *}$ & $-0.02(0.00)^{*}$ \\
\hline Square of the age difference & $-0.0004(0.03)^{* *}$ & $-0.0001(0.63)$ & $-0.001(0.02)^{* *}$ \\
\hline Square of the Education difference & $-0.0001(0.78)$ & $-0.001(0.05)^{* *}$ & $0.001(0.03)^{* *}$ \\
\hline First two born are of different gender & $-0.03(0.05)^{* *}$ & $-0.04(0.12)$ & $-0.02(0.22)$ \\
\hline Sum of Parent's Years of Education & $0.01(0.00)^{*}$ & $0.01(0.00)^{*}$ & $0.01(0.00)^{*}$ \\
\hline Child Age & $-0.02(0.87)$ & $-0.07(0.72)$ & $-0.003(0.98)$ \\
\hline Square of Child Age & $0.001(0.81)$ & $0.003(0.65)$ & $0.0003(0.96)$ \\
\hline Birth Order of the child & $-0.05(0.04)^{* *}$ & $-0.08(0.04)^{* *}$ & $-0.02(0.40)$ \\
\hline Square of Birth Order & $0.002(0.33)$ & $0.003(0.42)$ & $0.00(0.66)$ \\
\hline Child if Male & $-0.01(0.71)$ & $0.02(0.52)$ & $-0.02(0.40)$ \\
\hline Household headed by Male & $-0.43(0.00)^{*}$ & $-0.45(0.00)^{*}$ & $-0.42(0.00)^{*}$ \\
\hline Proportion of Female age 0-5 & $0.01(0.92)$ & $0.14(0.56)$ & $-0.04(0.79)$ \\
\hline Proportion of Female age 6-9 & $0.36(0.01)^{*}$ & $0.59(0.01)^{*}$ & $0.26(0.14)$ \\
\hline Proportion of Female age 10-14 & $0.52(0.00)^{*}$ & $0.59(0.00)^{*}$ & $0.52(0.00)^{*}$ \\
\hline Proportion of Female age 15-65 & $-0.10(0.33)$ & $-0.27(0.09)^{* * *}$ & $0.03(0.82)$ \\
\hline Proportion of Female age 65 or more & $0.35(0.15)$ & $0.35(0.39)$ & $0.45(0.14)$ \\
\hline Proportion of Male age 0-5 & $0.05(0.71)$ & $0.26(0.28)$ & $-0.06(0.74)$ \\
\hline Proportion of Male age 6-9 & $0.49(0.00)^{*}$ & $0.50(0.02)^{* *}$ & $0.51(0.00)^{*}$ \\
\hline Proportion of Male age 10-14 & $0.61(0.00)^{*}$ & $0.73(0.00)^{*}$ & $0.52(0.00)^{*}$ \\
\hline Proportion of Male age 65 or more & $-0.13(0.62)$ & $-0.39(0.36)$ & $0.02(0.94)$ \\
\hline Living standard Index & $0.06(0.00)^{*}$ & $0.01(0.43)$ & $0.09(0.00)^{*}$ \\
\hline Durable Asset Index & $0.04(0.00)^{*}$ & $0.06(0.00)^{*}$ & $0.01(0.44)$ \\
\hline Agricultural Land Ownership & $-0.05(0.06)^{* * *}$ & $-0.09(0.11)$ & $-0.02(0.45)$ \\
\hline Provincial Dummies: Punjab & $0.97(0.00)^{*}$ & $0.93(0.00)^{*}$ & $1.01(0.00)^{*}$ \\
\hline Sindh & $0.47(0.00)^{*}$ & $0.45(0.00)^{*}$ & $0.48(0.00)^{*}$ \\
\hline Balochistan & $-0.09(0.00)^{*}$ & $-0.19(0.00)^{*}$ & $-0.03(0.37)$ \\
\hline & & & \\
\hline
\end{tabular}




\begin{tabular}{|l|l|l|l|}
\hline Constant & $1.15(0.08)^{* * *}$ & $1.60(0.13)$ & $0.94(0.25)$ \\
\hline Number of Observation & 11209 & 4352 & 6857 \\
\hline Adjusted R-square & 0.28 & 0.28 & 0.28 \\
\hline F-statistics & 168.71 & 98.28 & 64.26 \\
\hline Prob. F-test & 0.00 & 0.00 & 0.00 \\
\hline
\end{tabular}

Note: $*, * * \& * * *$ represents significant at $1 \%, 5 \%$ \& $10 \%$ significance level. Numbers in parenthesis are P-values.

\section{Effect on Child Schooling}

After analyzing the factors determining mother's decision- making power, the study now explores its effect on her child's schooling. Table 2 shows that the effect is significant and positive in the model without control for household size and composition. A 10 percentage point increase in mother's decision- making power increases child schooling around 0.1 percentage point in all Pakistan sample. In urban areas a 10 percentage point increase in mother's decisionmaking power increases child schooling slightly by 0.1 percentage point while in the rural areas a 10 percentage point increase in mother's decision making power increases child schooling around 2.3 percentage points. The effect of mother's decision- making power is significant only in urban areas, once the fertility and demographic variables are entered in the model. In urban areas after entering the fertility and demographic variables, a 10 percentage point increase in mother's decision making power increases child schooling slightly by 0.1 percentage point.

As far as other explanatory variables are concerned the sum of mother and father's years of schooling appears to have significant positive effect on the child's schooling. An additional year of parental education increases the child schooling about 2 percentage points in all Pakistan sample while it increases the probability of child schooling about 1 percentage point in urban sample and 3 percentage point in rural sample. Among the variables representing child's own characteristics, age shows significant nonlinear effect in all Pakistan and in rural sample. In all Pakistan level precisely a one year increase in the age increases the probability of child schooling around 17 percentage points but as said earlier the effect is nonlinear. The result holds for both with and without fertility and demographic control models. As far as birth order is concerned, the effect is significant and nonlinear in all Pakistan and in urban areas only. In all Pakistan and in urban areas the probability of child schooling first increases with the number of sibling in the house but after a certain threshold it decreases the probability of a child to be in school.

Household accumulation of durable assets shows significant positive effect on child schooling. Ownership of agriculture land is also found to have significant and positive effect. Both ownership of asset and agriculture land represent household economic condition. The better the condition the higher is the 
probability for a child to be in school. Provincial dummies are also significant but negative in all Pakistan and in rural sample only except for Punjab province. However, the effect of Sindh province is also significant in urban areas as well. Furthermore, result also shows that children being in the male headed household are less likely to go to school. However the effect is insignificant in urban areas. Higher household size means lower will be the resources available for each child to be invested on his/her human capital formation. As far as household composition is concerned, proportion of girls' aged 10 -14 increases the probability of schooling at all Pakistan level only. Proportion of female age 15 or higher and male aged 65 or higher significantly increases child schooling. This could imply that the higher the number of adult in the house the higher will be the probability of adult to be at work then children. Overall finding indicates that the effect of mother's decision- making power on child schooling is highly significant and positive. Therefore we conclude that our results are consistent with the main hypothesis that mothers are more concerned for the welfare of the children than male members of the household.

Table: 2

Probit Model of Child Schooling (Estimated Coefficients)

\begin{tabular}{|c|c|c|c|c|c|c|}
\hline \multirow[t]{2}{*}{ Variables } & \multicolumn{3}{|c|}{ Without Fertility and demographic Control } & \multicolumn{3}{|c|}{ With Fertilityand demographic Control } \\
\hline & All Pakistan & Urban & Rural & All Pakistan & Urban & Rural \\
\hline MDM Index & $0.03(0.09)^{* * *}$ & $0.1(0.04)^{* *}$ & $0.64(0.07) * * *$ & $0.02(0.22)$ & $0.05(0.09)^{* * *}$ & $0.7(0.11)$ \\
\hline $\begin{array}{c}\text { Sum of Parent's Years of } \\
\text { Education }\end{array}$ & $0.07(0.00)^{*}$ & $0.06(0.0)^{*}$ & $0.07(0.00)^{*}$ & $0.07(0.00)^{*}$ & $0.06(0.00)^{*}$ & $0.07(0.00)^{*}$ \\
\hline Child Age & $0.53(0.01)^{*}$ & $0.35(0.30)$ & $0.60(0.01)^{*}$ & $0.5(0.01)^{*}$ & $0.34(0.32)$ & $0.60(0.01)^{*}$ \\
\hline Square of Child Age & $-0.03(0.00)^{*}$ & $-0.02(0.12)$ & $-0.03(0.00)^{*}$ & $-0.03(0.0)^{*}$ & $-0.02(0.12)$ & $-0.03(0.00)^{*}$ \\
\hline Birth Order of the child & & & & $0.1(0.01)^{*}$ & $0.22(0.00)^{*}$ & $0.13(0.22)$ \\
\hline Square of Birth Order & & & & $-0.01(0.0)^{*}$ & $-0.02(0.00)^{*}$ & $-0.01(0.15)$ \\
\hline Child if Male & $0.68(0.00)^{*}$ & $0.28(0.00)$ & $0.88(0.00)^{*}$ & $0.75(0.00)^{*}$ & $0.38(0.00)^{*}$ & $0.95(0.00)^{*}$ \\
\hline $\begin{array}{l}\text { Household headed by } \\
\text { Male }\end{array}$ & $-0.42(0.00)^{*}$ & $-0.3(0.01)^{*}$ & $-0.18(0.36)$ & $-0.3(0.0)^{*}$ & $-0.20(0.1)^{* * *}$ & $-0.03(0.86)$ \\
\hline Log of Household Size & & & & $-0.15(0.0)^{*}$ & $-0.25(0.00)^{*}$ & $-0.36(0.42)$ \\
\hline $\begin{array}{l}\text { Proportion of Female age } \\
0-5\end{array}$ & & & & $0.06(0.79)$ & $-0.66(0.14)$ & $0.20(0.64)$ \\
\hline $\begin{array}{l}\text { Proportion of Female age } \\
\qquad 6-9\end{array}$ & & & & $-0.05(0.86)$ & $-0.60(0.17)$ & $-0.29(0.61)$ \\
\hline $\begin{array}{c}\text { Proportion of Female age } \\
10-14\end{array}$ & & & & $0.74(0.00)^{*}$ & $0.56(0.15)$ & $0.23(0.67)$ \\
\hline $\begin{array}{l}\text { Proportion of Female age } \\
15-65\end{array}$ & & & & $1.09(0.00)^{*}$ & $0.76(0.02)^{* *}$ & $1.17(0.00)^{*}$ \\
\hline $\begin{array}{c}\text { Proportion of Female age } \\
65 \text { or more }\end{array}$ & & & & $1.45(0.00)^{*}$ & $1.76(0.05)^{* *}$ & $1.2(0.06)^{* * *}$ \\
\hline $\begin{array}{l}\text { Proportion of Male age 0- } \\
5\end{array}$ & & & & $-0.01(0.98)$ & $-0.65(0.14)$ & $0.12(0.78)$ \\
\hline $\begin{array}{c}\text { Proportion of Male age 6- } \\
9\end{array}$ & & & & $0.20(0.41)$ & $-0.06(0.90)$ & $-0.34(0.56)$ \\
\hline $\begin{array}{c}\text { Proportion of Male age } \\
10-14 \\
\end{array}$ & & & & $0.17(0.44)$ & $-0.28(0.46)$ & $-0.32(0.59)$ \\
\hline $\begin{array}{c}\text { Proportion of Male age } \\
65 \text { or more }\end{array}$ & & & & $0.9(0.05)^{* *}$ & $-0.58(0.49)$ & $1.87(0.00)^{*}$ \\
\hline Living standard Index & $0.07(0.00)^{*}$ & $0.04(0.18)$ & $-0.03(0.52)$ & $0.06(0.00)^{*}$ & $0.03(0.29)$ & $-0.05(0.30)$ \\
\hline Durable Asset Index & $0.32(0.00)^{*}$ & $0.29(0.0)^{*}$ & $0.32(0.00)^{*}$ & $0.32(0.00)^{*}$ & $0.29(0.00)^{*}$ & $0.34(0.00)^{*}$ \\
\hline
\end{tabular}




\begin{tabular}{|c|c|c|c|c|c|c|}
\hline $\begin{array}{c}\text { Agricultural Land } \\
\text { Ownership }\end{array}$ & $0.13(0.01)^{*}$ & $0.3(0.02)^{* *}$ & $0.13(0.03)^{* *}$ & $0.14(0.01)^{*}$ & $0.34(0.01)^{*}$ & $0.1(0.04)^{* *}$ \\
\hline $\begin{array}{c}\text { Provincial Dummies: } \\
\text { Punjab }\end{array}$ & $-0.04(0.30)$ & $-0.04(0.63)$ & $-0.68(0.06)^{* *}$ & $-0.07(0.11)$ & $-0.06(0.47)$ & $-0.8(0.05)^{* *}$ \\
\hline Sindh & $-0.43(0.00)^{*}$ & $-0.28(0.0)^{*}$ & $-0.80(0.00)^{*}$ & $-0.4(0.00)^{*}$ & $-0.29(0.00)^{*}$ & $-0.81(0.00)^{*}$ \\
\hline Balochistan & $-0.28(0.00)^{*}$ & $-0.10(0.21)$ & $-0.37(0.00)^{*}$ & $-0.3(0.00)^{*}$ & $-0.07(0.36)$ & $-0.36(0.00)^{*}$ \\
\hline constant & $-1.85(0.10)^{* * *}$ & $-0.62(0.76)$ & $-3.06(0.04)^{* *}$ & $-2.3(0.05)^{* *}$ & $-0.53(0.80)$ & $-2.94(0.13)$ \\
\hline Number of Observation & 11209 & 4352 & 6857 & 11209 & 4352 & 6857 \\
\hline Log Likelihood Ratio & -5317.41 & -1691.52 & -3562.46 & -5280.59 & -1670.27 & -3539.34 \\
\hline LR-statistics & 3155.26 & 787.83 & 1990.17 & 3228.9 & 830.35 & 2036.41 \\
\hline Prob. LR-statistics & 0.00 & 0.00 & 0.00 & 0.00 & 0.00 & 0.00 \\
\hline Pseudo R-square & 0.23 & 0.19 & 0.22 & 0.23 & 0.20 & 0.22 \\
\hline $\begin{array}{c}\text { Wald test of exogeneity: } \\
\text { chi2 }\end{array}$ & 0.91 & 0.12 & 3.41 & 1.28 & 0.69 & 5.18 \\
\hline Prob. $>$ chi2 & 0.34 & 0.73 & 0.06 & 0.52 & 0.71 & 0.08 \\
\hline $\begin{array}{c}\text { Amemiya-Lee-Newey } \\
\text { chi2 (OID-Test) }\end{array}$ & - & - & 1.47 & - & - & 3.64 \\
\hline P-value (OID-Test) & - & - & 0.20 & - & - & 0.30 \\
\hline
\end{tabular}

Note: $* * * \& * * *$ represents significant at $1 \%, 5 \%$ \& $10 \%$ significance level. Numbers in parenthesis are Pvalues. The endogeneity in the Decision making power and household size is control in all Pakistan and rural samples, where Wald tests of Exogeneity is significant i.e. predicting the endogeneity

\section{Disaggregating by Child Gender}

So far we have explored the effect of mother's decision- making power on her child's schooling at all Pakistan level and in urban and rural areas. However this effect may vary by gender. Gitter and Barham (2008) for Nicaragua find out that the mother relative education level to father had a positive impact on boy's education outcomes only. They also found that non-monotonic relation holds for girls but not for boys. Reggio (2010) working on Mexican data also observed that increase in mother's bargaining power is associated with fewer hours of work for her daughters but not for her sons. Keeping these in mind we also expect that the effect of mother's decision- making power may differ for boys and girls in Pakistan as well. Table 3 presents the result.

Table 3 shows that the effect of mother's decision- making power on her child's education is significant for both boys and girls sample. The effect is negative for labour while positive for schooling.

Furthermore, Gitter and Barham (2008) also found that the effect of mother's decision making power is non-monotonic for girls sample only. The Study also tries to explore the proposition by including quadratic and cubed terms in the model. The result shows that the effect is linear only. 
Table: 3

Probit Model of Schooling by Gender

\begin{tabular}{|c|c|c|c|c|}
\hline \multirow{2}{*}{ Dependent Variables } & \multicolumn{4}{|c|}{ Child Schooling } \\
\hline & Boys & Girls & Boys & Girls \\
\hline MDM Index & $0.92(0.21)$ & $-0.18(0.22)$ & $0.92(0.03) * *$ & $0.07(0.00) *$ \\
\hline $\begin{array}{l}\text { Square of Mother's DM } \\
\text { Index }\end{array}$ & $0.22(0.70)$ & $0.13(0.27)$ & & \\
\hline Cube of Mother's DM Index & $-0.10(0.49)$ & $-0.01(0.56)$ & & \\
\hline $\begin{array}{c}\text { Sum of Parent's Years of } \\
\text { Education }\end{array}$ & $0.06(0.00) *$ & $0.07(0.00) *$ & $0.06(0.00) *$ & $0.07(0.00) *$ \\
\hline Child Age & $0.83(0.00) *$ & $0.42(0.12)$ & $0.83(0.00) *$ & $0.43(0.11)$ \\
\hline Square of Child Age & $-0.04(0.00) *$ & $-0.03(0.03) * *$ & $-0.04(0.00) *$ & $-0.03(0.02) * *$ \\
\hline Birth Order of the child & $0.003(0.98)$ & $0.19(0.00) *$ & $-0.02(0.89)$ & $0.18(0.00) *$ \\
\hline Square of Birth Order & $-0.001(0.96)$ & $-0.02(0.00) *$ & $0.0001(0.99)$ & $-0.02(0.00) *$ \\
\hline Household headed by Male & $-0.08(0.79)$ & $-0.2(0.06) * * *$ & $-0.03(0.92)$ & $-0.22(0.02) * *$ \\
\hline Log of Household Size & $0.27(0.69)$ & $-0.28(0.00) *$ & $0.41(0.54)$ & $-0.27(0.00) *$ \\
\hline $\begin{array}{c}\text { Proportion of Female age } 0 \text { - } \\
5\end{array}$ & $0.95(0.09)^{* * *}$ & $-0.36(0.30)$ & $0.9(0.08)^{* * *}$ & $-0.35(0.30)$ \\
\hline $\begin{array}{c}\text { Proportion of Female age 6- } \\
9 \\
\end{array}$ & $0.05(0.95)$ & $-0.11(0.77)$ & $0.22(0.80)$ & $-0.11(0.77)$ \\
\hline $\begin{array}{c}\text { Proportion of Female age } \\
10-14\end{array}$ & $0.44(0.44)$ & $0.65(0.04) * *$ & $0.52(0.36)$ & $0.65(0.04) * *$ \\
\hline $\begin{array}{c}\text { Proportion of Female age } \\
15-65\end{array}$ & $1.24(0.00) *$ & $1.14(0.00) *$ & $1.20(0.00) *$ & $1.15(0.00) *$ \\
\hline $\begin{array}{l}\text { Proportion of Female age } 65 \\
\text { or more }\end{array}$ & $1.94(0.01) *$ & $0.88(0.17)$ & $1.84(0.01) *$ & $0.89(0.16)$ \\
\hline Proportion of Male age $0-5$ & $0.67(0.21)$ & $-0.33(0.33)$ & $0.73(0.17)$ & $-0.32(0.35)$ \\
\hline Proportion of Male age 6-9 & $0.33(0.71)$ & $0.03(0.94)$ & $0.50(0.57)$ & $0.04(0.90)$ \\
\hline $\begin{array}{c}\text { Proportion of Male age 10- } \\
14\end{array}$ & $0.16(0.90)$ & $0.40(0.20)$ & $0.39(0.76)$ & $0.42(0.18)$ \\
\hline $\begin{array}{c}\text { Proportion of Male age } 65 \text { or } \\
\text { more }\end{array}$ & $0.96(0.29)$ & $1.14(0.09)^{* * *}$ & $0.86(0.35)$ & $1.17(0.08) * * *$ \\
\hline Living standard Index & $-0.1(0.07)^{* * *}$ & $0.18(0.00) *$ & $-0.08(0.08) * * *$ & $0.18(0.00) *$ \\
\hline Durable Asset Index & $0.22(0.00) *$ & $0.37(0.00) *$ & $0.22(0.00) *$ & $0.37(0.00) *$ \\
\hline $\begin{array}{l}\text { Agricultural Land } \\
\text { Ownership }\end{array}$ & $0.25(0.01) *$ & $0.10(0.18)$ & $0.24(0.01) *$ & $0.10(0.17)$ \\
\hline Provincial Dummies: Punjab & $-1.35(0.00) *$ & $0.18(0.00) *$ & $-1.28(0.00) *$ & $0.19(0.00) *$ \\
\hline Sindh & $-1.03(0.00) *$ & $-0.33(0.00) *$ & $-0.96(0.00) *$ & $-0.35(0.00) *$ \\
\hline Balochistan & $-0.1(0.10)^{* * *}$ & $-0.37(0.00) *$ & $-0.16(0.05) * *$ & $-0.37(0.00) *$ \\
\hline Constant & $-4.9(0.05) * *$ & $-1.45(0.37)$ & $-5.21(0.04) * *$ & $-1.54(0.34)$ \\
\hline Number of Observation & 5683 & 5526 & 5683 & 5526 \\
\hline Log Likelihood Ratio & -2460.56 & -2669.9 & -2462.02 & -2674.83 \\
\hline LR-statistics & 964.12 & 2097.97 & 961.20 & 2088.14 \\
\hline Prob. LR-statistics & 0.000 & 0.00 & 0.00 & 0.00 \\
\hline Pseudo R-square & 0.164 & 0.28 & 0.16 & 0.28 \\
\hline Wald test of exogeneity: chi2 & - & - & 5.60 & 1.36 \\
\hline Prob. $>$ chi2 & - & - & 0.06 & 0.51 \\
\hline Amemiya-Lee-Newey chi2 & - & - & 1.4 & - \\
\hline P-value (OID-Test) & - & - & 0.71 & - \\
\hline
\end{tabular}

Note: *, **\& \&** represents significant at $1 \%, 5 \% \& 10 \%$ significance level. Numbers in parenthesis are $P$ values. The endogeneity in the Decision making power and household size is checked using Wald tests of 
Exogeneity. As the test values are insignificant i.e. not predicting the endogeneity, both household size and decision making index considered exogenous.

\section{Conclusions}

In Pakistan strict social and cultural norms imply that men are often considered to have dominating roles in decision- making while women are often perceived to have limited impacts on decisions. But this perceived role is now changing and researchers are turning to collective approaches to model the effect of women's decision- making power on child related outcomes. For example Hou (2011) had rejected the unitary model approach for Pakistan and found that the effect of women bargaining power on education expenditure is positive and significant. Our work can be considered in line with the study done by Hou (2011). Hou (2011) looks at the effect of women's power on the household expenditure pattern on food, lighting transport and education expenditure. But in this study we have explored explicitly its effect on child schooling decisions.

Further to this, acknowledging the theoretical prediction of Basu (2006), this study has also examined whether effect of mother's decision making power on her child's schooling is non-monotonic. Using the Pakistan Standard of Living Measurement Survey Data for 2007-8 this article has provided evidence that the intra-household distribution of power does affects child schooling. The study also shows that the effect of any additional power given to mother's increases child schooling but the effect is linear only. The data fails to predict the Basu's hypothesis in case of Pakistan.

\section{References}

Amin, S. (1995). The Poverty-Purdah Trap in Rural Bangladesh: Implications for Women Roles in the Family, Working Paper, New York, Research Division, The Population Council.

Baland J. M. \& J.A. Robinson (2000). Is Child labour Inefficient?, Journal of Political Economy, Chicago Press, vol.108:4, pp.663-679.

Basu, K. (2006). Gender and Say: A Model of Household Behaviour with Endogenously Determined Balance of Power, Economic Journal, vol.116, pp.558-580.

Basu, K. \& P. H. Van (1998). The Economics of Child Labour, American Economic Review, vol.88:3, pp.412-427. 
Bell, Clive \& Hans Gersbach (2000). Child Labour and the Education of a Society, IZA Discussion Paper No.338, Institute for the Study of Labour, Bonn.

Dessy, S., (2000). A Defense of Compulsory Measures against Child Labour, Journal of Development Economics, vol.62:1, pp.261-275.

Doss, C.R. (1996). Testing among Models of Intra-Household Resource Allocation, World Development, vol.24:10, pp.1597-1609.

Emerson, P. \& A. P. Souza (2003). Is There a Child Labour Trap? InterGenerational Persistence of Child Labour in Brazil, Economic Development and Cultural Change, vol.51:2, pp.375-398.

Emerson, P. \& A. P. Souza (2007). Child Labour, School Attendance, and IntraHousehold Gender Bias in Brazil, The World Bank Economic Review, vol.21:2, pp. 301-316

Felkey, A. J. (2005). Husbands, Wives and the Peculiar Economics of Household Public Goods and Bads, Seminar Presentation, Brown Bag Seminar, Federal Reserve Bank of Chicago, Chicago, IL, US.

Galasso, E. (1999). Intra-household Allocation and Child Labour in Indonesia, Manuscript, Boston College.

Gitter, S. R. \& B. L. Barham (2008). Women's Power, Conditional Cash Transfers, and Schooling in Nicaragua, the World Bank Economic Review, vol.22:2, pp.271-290.

Grootaert, C. \& H. A. Patrinos (eds.) (1999). Policy Analysis of Child Labour: A Comparative Study, New York, St. Martin's Press.

Hakim, A. \& A. Aziz (1998). Socio-cultural, Religious, and Political Aspects of the Status of Women in Pakistan, The Pakistan Development Review, vol.37:4, pp.727-746.

Hoddinott, J. \& L. Haddad (1995). Does Female Income Share Influence Household Expenditures? Evidence from Cote D'Ivoire, Oxford Bulletin of Economics and Statistics, vol.57:1, pp. 77-95.

Hou Xi. (2011). Women's Decision Making Power and Human Development: Evidence from Pakistan, Policy Research Working Paper No.5830, The World Bank. 
Jensen, P. \& H. S. Nielsen (1997). Child Labour or School Attendance? Evidence from Zambia, Journal of Population Economics, vol.10:4, pp.407-424.

Lancaster, G., Maitra, P. \& Ray, R. (2006). Endogenous Intra-household Balance of Power and its Impact on Expenditure Patterns: Evidence from India, Economica, vol.73, pp.435-460.

Lundberg, S., R. Pollak, \& T. Wales (1997). Do Husbands and Wives Pool Their Resources? Evidence from the United Kingdom Child Benefit, Journal of Human Resources, vol.32:3, pp.463-480.

Maitra, P. \& Ranjan R. (2006). Household Expenditure Patterns and Resource Pooling: Evidence of Changes in Post-Apartheid South Africa. Review of Economics of the Household, vol.4:4, pp. 325-347.

PSLM (2007-08). Pakistan Standard of Living Measurement Survey, Federal Bureau of Statistics, Pakistan.

Quisumbing, A.R. (1994). Intergenerational Transfers in Philippine Rice Villages: Gender Differences in Traditional Inheritance Customs, Journal of Development Economics, vol.43:2, pp.167-195.

Ranjan R. (2000). Analysis of Child Labour in Peru and Pakistan: A Comparative Study, Journal of Population Economics, vol.13:1, pp.3-19.

Reggio I. (2010). The Influence of the Mother's Power on her Child's Labour in Mexico, Working Paper, 10-13, Economic Series, 05, Departamen to de Economía, Universidad Carlos III de Madrid.

Roushdy \& Namoro (2007). Intra-Household Resource Allocation in Egypt: Effect of Distribution of Power within the Household on Child Work and Schooling", University of Pittsburgh, Department of Economics, Working Papers No.331.

Rubalcava, L. \& D. Thomas (1997). Family Bargaining and Welfare, RAND mimeo.

Schultz, T. P. (1990). Testing the Neoclassical Model of Family Labour Supply and Fertility", Journal of Human Resources, vol.25:4, pp.599-634.

Thomas, D. (1990). Intra-Household Resource Allocation: An Inferential Approach, Journal of Human Resources, vol.25:4, pp.635-664. 
Thomas, D., D. Contreras \& E. Frankenberg (1997). Child Health and the Distribution of Household Resources at Marriage, RAND mimeo.

Ambreen Fatima is an Associate Professor in the Applied Economics Research Centre, (AERC) University of Karachi.

Faizan Iftikhar is an Assistant Professor in the Applied Economics Research Centre, (AERC) University of Karachi.

Humera Sultana is Research Assistant in the Applied Economics Research Centre, (AERC) University of Karachi. 